\title{
Hubungan antara efikasi diri dan burnout pada perawat RSUD Kota Soe Kabupaten Timor Tengah Selatan
}

\author{
Ratih Devi Aryantia,1, Siti Mulyanib,2* \\ aPT. Citra Borneo Indah, Kotawaringin Barat \\ bFakultas Psikologi, Universitas Ahmad Dahlan, Yogyakarta \\ ${ }^{1}$ ratihdeviaryanti@gmail.com; *2siti.mulyani@psy.uad.ac.id \\ *Correspondent Author
}

Received: 08-11-2020

Revised: 02-04-2021

Accepted: 26-07-2021

\begin{tabular}{|c|c|}
\hline KAT A KUNCI & ABSTRAK \\
\hline $\begin{array}{l}\text { burnout; } \\
\text { dukungan sosial keluarga; } \\
\text { efikasi diri }\end{array}$ & $\begin{array}{l}\text { Perawat merupakan profesi yang memiliki risiko mengalami burnout. } \\
\text { Hal ini dikarenakan tugas rutin dan tuntutan pekerjaan untuk } \\
\text { bertindak cepat dalam upaya penyelamatan pasien. Penelitian ini } \\
\text { bertujuan untuk menguji secara simultan hubungan antara efikasi diri } \\
\text { dan dukungan sosial keluarga dengan burnout perawat di Rumah } \\
\text { Sakit. Metode yang digunakan pada penelitian ini adalah kuantitatif } \\
\text { dengan desain korelasi. Sampel penelitian ini adalah } 30 \text { orang } \\
\text { perawat Rumah Sakit Umum Daerah Kota Soe yang diperoleh melalui } \\
\text { teknik simple random sampling. Variabel pada penelitian diukur } \\
\text { dengan menggunakan skala efikasi diri, skala dukungan sosial } \\
\text { keluarga dan skala burnout. Analisis data yang digunakan pada } \\
\text { penelitian ini adalah analisis regresi berganda dengan bantuan SPSS } \\
\text { versi } 16.0 \text { for windows. Hasil analisis data menunjukkan adanya } \\
\text { hubungan yang sangat signifikan antara efikasi diri dan dukungan } \\
\text { sosial keluarga dengan burnout perawat. Hasil analisis dengan } \\
\text { korelasi product moment Pearson juga menjelaskan ada hubungan } \\
\text { negatif yang sangat signifikan antara efikasi diri dengan burnout } \\
\text { perawat dan sumbangan efektifnya sebesar 7,556\%. Selanjutnya, } \\
\text { adanya hubungan negatif yang sangat signifikan antara dukungan } \\
\text { sosial keluarga dengan burnout perawat dan sumbangan efektifnya } \\
\text { sebesar 16,51\%. Hasil penelitian ini menyimpulkan bahwa secara } \\
\text { simultan ada hubungan antara efikasi diri dan dukungan sosial } \\
\text { keluarga dengan burnout perawat di Rumah Sakit Umum Daerah Kota } \\
\text { Soe. }\end{array}$ \\
\hline
\end{tabular}

KEYWORDS

burnout;

family social support; self-efficacy
The relationship between self-efficacy and burnout on nurses at the Soe City General Hospital, Timor Tengah Selatan Regency

Nursing is a profession that has a risk of experiencing burnout. This is due to routine tasks and work demands to act quickly in an effort to save patients. This study aims to simultaneously examine the relationship between self-efficacy and family social support with nurse burnout at the hospital. The method used in this study is quantitative with a correlation design. The sample of this study was 30 nurses at the Soe City Regional General Hospital obtained through simple random sampling technique. The variables in the study were measured using the self-efficacy scale, family social support scale and burnout scale. Analysis of the data used in this study is multiple regression analysis with the help of SPSS version 16.0 for windows. The results of data 
analysis showed a very significant relationship between self-efficacy and family social support with nurse burnout. The results of the analysis with Pearson's product moment correlation also explained that there was a very significant negative relationship between self-efficacy and nurse burnout and its effective contribution was 7.556\%. Furthermore, there is a very significant negative relationship between family social support and nurse burnout and its effective contribution is $16.51 \%$. The results of this study conclude that there is a simultaneous relationship between self-efficacy and family social support with nurse burnout at the Soe City Regional General Hospital.

This is an open-access article under the CC-BY-SA license.

\section{Pendahuluan}

Rumah sakit adalah tempat pelayanan kesehatan bagi masyarakat. Menurut UU RI No. 44 Tahun 2009, rumah sakit adalah instusi pelayanan kesehatan yang menyelenggarakan pelayanan kesehatan perorangan secara paripurna yang menyediakan pelayanan rawat inap, rawat jalan, dan gawat darurat (Pemerintah Pusat, 2009). Keterbatasan tenaga medis seperti dokter spesialis merupakan problematika yang terdapat pada rumah sakit daerah. Berdasarkan data yang diperoleh, Rumah Sakit Umum Daerah (RSUD) Kota Soe hanya memiliki 15 dokter dan jumlah tersebut lebih sedikit dibanding rata-rata jumlah dokter rumah sakit di Nusa Tenggara Timur. Jumlah perawat di Rumah Sakit Umum Daerah Kota Soe berjumlah 68 orang perawat dan tempat tidur untuk rawat inap berjumlah 100. Kondisi tersebut sudah sesuai dengan peraturan menteri kesehatan Republik Indonesia pasal 15 ayat 5 yang menyatakan bahwa "perbandingan tenaga keperawatan dan tempat tidur adalah 2:3" (Kementrian Kesehatan, 2010). Oleh karena itu, keadaan tersebut menjadikan rumah sakit ini telah memenuhi standar sesuai dengan peraturan menteri kesehatan.

Kondisi dari RSUD Kota Soe menunjukkan bahwa jumlah dokter di rumah sakit tersebut tergolong kurang, tetapi jumlah perawatnya telah memenuhi standar sesuai dengan peraturan menteri kesehatan, Berdasarkan data tersebut secara ideal selayaknya perawat tidak memiliki beban kerja yang tinggi, karena jumlah perawat sudah sesuai dengan standar yang telah ditetapkan. Namun secara realitas di lapangan menunjukan hal sebaliknya, mengingat tugas dari perawat diantaranya bertanggung jawab secara langsung dalam memberikan asuhan keperawatan kepada pasien, melakukan komunikasi dua arah kepada perawat lain, dokter dan tenaga kesehatan yang tergabung dalam tim, termasuk mennjadi pelaksana dalam kegiatan menyiapkan peralatan dan obat-obatan serta kegiatan administrasi berupa pencatatan dan pelaporan kegiatan keperawatan. Dengan demikian, tuntutan tugas tersebut berpeluang besar untuk dapat mempengaruhi munculnya stres terhadap perawat dalam melaksanakan pekerjaan. Hal ini sesuai dengan yang disampaikan oleh Putra dan Fihir (2013) bahwa tuntutan pekerjaan yang tinggi membuat perawat pelaksana lebih rentan mengalami stres kerja, bahkan mengalami burnout (Prestiana \& Purbandini, 2012).

Menurut Shaufeli dan Janczur (1994), dalam situasi kerja perawat terdapat stresor kerja objektif dan situasi kerja subjektif, yang berkaitan dengan burnout. Situasi kerja objektif meliputi jumlah jam kerja dalam seminggu, team size, pengalaman kerja, masa kerja, frekuensi dan lamanya kontak langsung dengan pasien. Stresor kerja subjektif meliputi ketidakpastian mengenai tidak adanya kejelasan tentang apa yang harus dilakukan berkenaan dengan perannya, ketidakseimbangan antara apa yang telah diberikan dan yang diperoleh dalam berhubungan dengan pasien. Stresor subjektif ketiga adalah tidak adanya kontrol yang berkaitan dengan kesembuhan pasien, keputusan dokter, dan administrasi 
rumah sakit.

Burnout merupakan proses psikologis yang dihasilkan oleh stres pekerjaan yang tidak terselesaikan dan menghasilkan kelelahan emosi, perubahan kepribadian, dan perasaan pencapaian yang menurun (Ivancevich \& Matteson, 1993). Aspek-aspek burnout menurut (Maslach, 1998) meliputi kelelahan emosional (emotional exhaustion) yaitu habisnya sumbersumber emosional dari dalam individu, depersonalisasi yaitu kecenderungan individu untuk menjauhi lingkungan sosialnya, bersikap sinis, apatis, tidak berperasaan, tidak peduli terhadap lingkungan, dan orang-orang sekitarnya, serta rendahnya penghargaan atas diri sendiri (low personal accomplishment). Dampak burnout pada perawat akan berpengaruh terhadap kinerja perawat baik di Rumah Sakit negeri maupun swasta karena karena efektivitas kerja berkurang, Para pengguna layanan kesehatan juga mengeluhkan penurunan kualitas pelayanan kesehatan yang diberikan perawat (Ramada \& Fadlan, 2016). Hal ini sesuai dengan hasil penelitian yang dilakukan oleh Djara (2013), yang menunjukan bahwa kelelahan kerja yang dialami oleh para perawat RSUD Kota Soe ternyata dirasakan langsung oleh pasien dan juga keluarga pasien. Artinya, bentuk dari kelelahan kerja perawat RSUD Kota Soe berimbas pada menurunnya kualitas pelayanan di Rumah Sakit tersebut.

Faktor-faktor yang dapat mempengaruhi burnout adalah faktor eksternal dan faktor internal. Faktor eksternal meliputi lingkungan kerja psikologis yang kurang baik, kurangnya kesempatan untuk promosi, imbalan yang diberikan tidak mencukupi, kurangnya dukungan sosial dari atasan, tuntutan pekerjaan, pekerjaan yang monoton, dan faktor internal meliputi usia, jenis kelamin, harga diri, dan karakteristik kepribadian (Baron \& Greenberg, 1990).

Menurut Baron dan Greenberg (1990) salah satu faktor internal yang mempengaruhi burnout adalah faktor kepribadian, dan salah satu aspek kepribadian tersebut adalah efikasi diri. Bandura (1972) mengungkapkan bahwa efikasi diri adalah keyakinan bahwa seseorang dapat menguasai suatu situasi dan menghasilkan luaran yang positif. Bandura (1972) juga mengungkapkan bahwa efikasi diri terkait dengan sejumlah perkembangan positif dalam kehidupan seseorang, di antaranya pemecahan masalah, lebih mudah bergaul dan bersosialisasi, berusaha dalam melakukan koping terhadap stress, serta dapat bertahan dalam hambatan. Dengan demikian, perawat yang memiliki efikasi diri tinggi akan memiliki keyakinan diri dan dapat mengantisipasi terkenanya burnout sehingga dapat mencari jalan keluar yang terbaik, mampu melaksanakan tugas, dan dapat mendukung orientasi untuk mencapai keberhasilan. Sebaliknya, jika perawat memiliki efikasi diri yang rendah maka kondisi tersebut dapat mempengaruhi perilaku kerja perawat, dan perawat cenderung menghindari tugas serta masalah yang dialami dalam rangka mengurangi tekanan emosionalnya (Lailani, 2014). Pendapat ini selaras dengan hasil penelitian yang dilakukan oleh Alverina dan Ambarwati (2019) yang menunjukkan bahwa efikasi diri perawat psikiatri mempunyai hubungan yang negatif dengan burnout.

Faktor lain mempengaruhi burnout adalah dukungan sosial. Dukungan sosial adalah informasi dan umpan balik dari orang lain yang menunjukan bahwa seseorang dicintai dan diperhatikan, dihargai, dan dihormati, dan dilibatkan dalam jaringan komunikasi dan kewajiban yang timbal baik (King, 2014). Dukungan sosial dalam penelitian ini lebih ditekankan pada dukungan yang diberikan oleh keluarga yaitu anggota keluarga baik ayah, ibu, saudara kandung atau orang seisi rumah. Menurut (Taylor, 2017) dukungan sosial dapat diperoleh dari keluarga dan orangtua. Individu yang memiliki dukungan sosial keluarga yang tinggi mengalami hal yang positif dalam kehidupannya, mempunyai harga diri yang lebih tinggi dan berpandangan lebih optimis terhadap kehidupannya dibanding yang mendapat dukungan sosial keluarga yang rendah.

Atkinson (1993) menjelaskan bahwa dukungan sosial keluarga berperan sebagai pelindung untuk melawan perubahan peristiwa kehidupan yang penuh stres. Melalui dukungan sosial keluarga, kesejahteraan psikologis akan meningkat karena adanya perhatian 
dan pengertian. Hal tersebut akan menimbulkan perasaan memiliki, meningkatkan harga diri dan kejelasan identitas diri serta memiliki perasaan positif mengenai diri sendiri. Dukungan sosial keluarga dan adanya perhatian orang lain dapat membuat orang tahan terhadap tekanan yang menimbulkan burnout (Andarika, 2004).

Dukungan sosial keluarga dapat membantu perawat untuk mendapatkan bantuan dukungan dan semangat dalam melaksanakan tugas-tugasnya dengan baik sehingga mampu menghadapi dan mengatasi masalah dalam bekerja. Smet (1994) mengungkapkan bahwa salah satu faktor yang dapat mengubah pengalaman stres adalah mencari dukungan sosial. Pendapat tersebut selaras dengan hasil penelitian Pangastiti (2011) bahwa dukungan sosial keluarga berpengaruh signifikan terhadap burnout, dukungan sosial yang diberikan keluarga diharapkan oleh individu agar segala keadaan menjadi lebih baik. Menurut Sarafino dan Smith (2014), dukungan sosial merupakan cara untuk menunjukkan kasih sayang, kepedulian, dan penghargaan untuk orang lain. Individu yang menerima dukungan sosial akan merasa dirinya dicintai, dihargai, berharga, dan merupakan bagian dari lingkungan sosialnya. Kondisi tersebut sejalan dengan hasil penelitian yang dilakukan oleh Lailani (2012) yang menunjukan adanya hubungan antara dukungan sosial dengan burnout pada perawat. Adanya dukungan sosial yang didapatkan dari keluarga dapat membantu perawat menanggulangi terkenanya burnout. Dukungan sosial keluarga sebagai support dari keluarga menjadikan perawat dapat mencari jalan keluar dari permasalahannya dan dapat menanggulangi permasalahan burnout.

Berdasarkan uraian di atas, peneliti bertujuan untuk menguji hubungan antara efikasi diri dan dukungan sosial keluarga dengan burnout pada perawat di Rumah Sakit Umum Daerah (RSUD) Kota Soe. Adapun hasil dari penelitian ini diharapkan dapat berkontribusi bagi pengembangan ilmu psikologi, khususnya psikologi industri organisasi. Manfaat lain yang diharapkan bahwa hasil penelitian ini dapat menjadi pengetahuan bagi para petugas kesehatan, khususnya perawat untuk mengetahui peranan dari efikasi diri dan dukungan sosial keluarga terhadap potensi terjadinya burnout. Dengan demikian hipotesis mayor pada penelitian ini adalah ada hubungan antara antara efikasi diri dan dukungan sosial keluarga dengan burnout perawat di RSUD Kota Soe. Sementara hipotesis minor pada penelitian ini yaitu ada hubungan negatif antara efikasi diri dengan burnout perawat di RSUD Kota Soe, serta ada hubungan negatif antara dukungan sosial keluarga dengan burnout perawat di RSUD Kota Soe.

\section{Metode}

Metode yang digunakan pada penelitian ini adalah kuantitatif dengan desain korelasi. Populasi penelitian ini adalah perawat RSUD Kota SoE. Teknik sampling yang digunakan dalam penelitian ini adalah simple random sampling. Simple random sampling yaitu teknik pengambilan sampel yang dilakukan dengan cara mengundi nama-nama subjek dalam populasi (Azwar, 1999), sehingga dari 68 perawat RSUD Kota SoE bagian pelayanan IRNA diperoleh subjek penelitian sebanyak 30 subjek.

Alat pengmpulan data yang digunakan pada penelitian ini adalah skala. Pengukuran variabel burnout menggunakan skala burnout yang dimodifikasi dari Maslach Burnout Inventory (MBI) (Maslach \& Jackson, 1981) dengan koefisien reliabilitas Alpha pada penelitian ini $\mathrm{rtt}=0,819$. Pengukuran variabel efikasi diri menggunakan skala efikasi diri yang disusun oleh peneliti berdasarkan aspek-aspek efikasi diri yang dikemukakan oleh Bandura (1972) dengan koefisien reliabilitas Alpha pada penelitian ini $\mathrm{rtt}=0,921$. Pengukuran dukungan sosial keluarga menggunakan skala dukungan sosial keluarga yang disusun oleh peneliti berdasarkan dimensi objek variabel yang dikemukakan oleh Sarafino dan Smith (2014) dengan koefisien reliabilitas Alpha pada penelitian ini rtt=0,942.

Teknik analisis data yang digunakan dalam penelitian adalah analisis regresi berganda. Sebelum dilakukan analisis dengan menggunakan analisis regresi berganda, terlebih dahulu dilakukan uji asumsi yang meliputi uji normalitas, uji linieritas, dan uji multikolinieritas. 


\section{Hasil}

Berdasarkan hasil uji normalitas, dapat diketahui bahwa variabel burnout memiliki $p=0,733(p>0,05)$. Variabel efikasi diri memiliki $p=0,626(p>0,05)$. Variabel dukungan sosial keluarga memiliki $\mathrm{p}=0,195$ ( $\mathrm{p}>0,05)$. Dengan demikian, berdasarkan hasil uji normalitas tersebut dapat disimpulkan bahwa masing-masing variabel penelitian memiliki sebaran data yang terdistribusi normal.

Hasil pengujian linieritas antara variabel burnout dan efikasi diri menunjukkan taraf signifikansi $\mathrm{p}$ (linearity) sebesar $0,000(\mathrm{p}<0,05)$ yang berarti bahwa data bersifat linier. Sedangkan antara variabel burnout dan dukungan sosial keluarga menunjukkan taraf signifikansi $p$ (linearity) sebesar $0,008(\mathrm{p}<0,05)$ yang berarti juga bersifat linier. Selanjutnya hasil uji multikolinieritas antara variabel efikasi diri dan dukungan sosial keluarga menunjukkan nilai VIF (Variance Inflation Factor) sebesar 1,446 (0,1) dan nilai tolerance sebesar 0,692 $(>0,1)$ sehingga dapat disimpulkan bahwa tidak terjadi multikolinearitas antar variabel bebas.

Berdasarkan hasil penghitungan analisis regresi berganda diperoleh koefisien regresi antara efikasi diri dan dukungan sosial keluarga dengan burnout sebesar $\mathrm{R}=0,594$ dengan $p=0,003(p<0,01)$. Berdasarkan hasil analisis tersebut dapat disimpulkan bahwa terdapat korelasi yang sangat signifikan antara efikasi diri dan dukungan sosial keluarga dengan burnout. Hasil analisis regresi berganda dapat dilihat pada tabel 1 .

Tabel 1.

Hasil Analisis Regresi

\begin{tabular}{lll}
\hline Variabel & $\boldsymbol{R}$ & $\boldsymbol{p}$ \\
\hline Efikasi diri \& dukungan sosial keluarga terhadap burnout & 0,549 & 0,003 \\
\hline
\end{tabular}

Hasil uji korelasi product moment antara variabel efikasi diri dengan burnout menunjukan koefisien korelasi rxy=-0,537 dengan taraf signifikansi $p=0,001 \quad(p<0,01)$. Berdasarkan hasil analisis tersebut dapat disimpulkan bahwa ada hubungan negatif yang sangat signifikan antara efikasi diri dengan burnout perawat RSUD Soe. Hubungan antara efikasi diri dengan burnout bersifat negatif, artinya jika efikasi diri tinggi maka burnout yang dimiliki perawat akan semakin rendah, sebaliknya jika efikasi diri rendah maka burnout yang dimiliki perawat akan semakin tinggi. Hasil korelasi antara dukungan sosial keluarga dengan burnout menunjukan koefisien korelasi $r x y=-0,510$ dengan taraf signifikansi $p=0,002$ $(\mathrm{p}<0,01)$. Berdasarkan hasil analisis tersebut dapat disimpulkan bahwa ada hubungan negatif yang sangat signifikan antara dukungan sosial keluarga dengan burnout perawat RSUD Soe. Hubungan antara dukungan sosial keluarga dengan burnout bersifat negatif, artinya jika dukungan sosial keluarga tinggi maka burnout yang dimiliki akan semakin rendah, sebaliknya jika dukungan sosial keluarga rendah maka burnout yang dimiliki perawat akan semakin tinggi. Hasil uji korelasi product moment Pearson dapat dilihat pada tabel 2.

Tabel 2.

Korelasi Product Momen Pearson

\begin{tabular}{lll}
\hline Variabel & $\boldsymbol{r}$ & $\boldsymbol{p}$ \\
\hline Efikasi diri * burnout & $-0,537$ & 0,001 \\
Dukungan sosial keluarga* burnout & $-0,510$ & 0,002 \\
\hline
\end{tabular}

\section{Pembahasan}

Hasil penelitian menunjukkan adanya hubungan yang sangat signifikan antara efikasi diri dan dukungan sosial keluarga dengan burnout pada perawat RSUD Soe. Artinya, efikasi 
diri dan dukungan sosial keluarga secara bersama-sama memberikan pengaruh terhadap tinggi rendahnya burnout pada perawat.

Hasil analisis korelasi product moment Pearson menunjukan bahwa ada hubungan negatif yang sangat signifikan antara efikasi diri dengan burnout dimana hal ini menunjukkan bahwa semakin tinggi efikasi diri maka semakin rendah burnout dan sebaliknya. Hasil analisis data menunjukan sumbangan efektif dari variabel efikasi diri sebesar 7,556\%, yang artinya efikasi diri mempengaruhi burnout. Menurut Bandura (1972), dan King (2014) efikasi diri terkait dengan sejumlah perkembangan positif dalam kehidupan seseorang diantaranya, pemecahan masalah, lebih mudah bergaul dan bersosialisasi, berusaha dalam melakukan coping terhadap stres, serta dapat bertahan dalam hambatan. Efikasi diri juga membantu orang-orang dalam berbagai situasi yang tidak memuaskan dengan mendorong mereka untuk menyakini bahwa mereka dapat berhasil.

Hasil penelitian ini sejalan dengan penelitian yang dilakukan Lailani (2012) bahwa kuat lemahnya efikasi diri yang dimiliki perawat akan berperan terhadap tinggi rendahnya burnout yang dialami perawat. Efikasi diri yang tinggi dapat membuat perawat berani dan mampu menghadapi tugas-tugasnya yang berpeluang menimbulkan stres. Keyakinan untuk dapat menyelesaikan tugas-tugasnya dapat menjadi mekanisme yang menggerakkan seluruh kemampuan kognitif, emosi, dan keterampilan yang dimilikinya untuk menghadapi tugastugas yang harus diselesaikan. Kemudian penelitian Prestina dan Purbandini (2012) juga menunjukkan hasil yang serupa yakni menunjukkan bahwa terdapat hubungan negatif antara variabel efikasi diri dengan variabel burnout perawat RSUD Kota Bekasi. Artinya, semakin tinggi tingkat efikasi diri perawat maka semakin rendah burnoutnya, dengan diperoleh hasil koefisien korelasi sebesar $r=-0.470$ dan tingkat signifikansi $0.003(p<0.05)$.

Sejalan dengan pendapat yang dikemukakan Baron dan Greenberg (1990), salah satu faktor yang dapat mempengaruhi burnout adalah faktor internal dimana karakteristik kepribadian yang di dalamnya terdapat efikasi diri. Efikasi diri yang tinggi sangat penting dimiliki oleh perawat yang sedang menghadapi pasien dengan berbagai macam karakteristik individu karena efikasi diri merupakan persepsi atau keyakinan individu akan kemampuan diri sendiri yang akan ikut mempengaruhi kinerja perawat dalam mencapai keberhasilan dalam pekerjaannya, dan kepercayaan perawat untuk menentukan bagaimana perawat merasa, berfikir, memotivasi dan berperilaku kemudian perawat percaya akan kemampuannya untuk meningkatkan kinerjanya. Sulistyowati (2010) dalam penelitiannya menjelaskan bahwa efikasi diri yang dimiliki individu dikaitkan dengan strategi mengatasi burnout yang dihadapi. Perawat dengan efikasi diri tinggi cenderung menggunakan strategi problem focusing coping, perawat akan berusaha mencari jalan untuk memecahkan masalah yang dihadapinya untuk memperbaiki situasi kerja di rumah sakit. Sedangkan perawat dengan efikasi diri rendah akan cenderung menggunakan strategi emotion focused coping, dimana perawat cenderung hanya mengatasi emosi yang timbul pada saat menghadapi masalah di rumah sakit. Efikasi diri yang tinggi yang dimiliki perawat dapat menjadikan perawat mampu menghadapi tugas-tugasnya yang kompleks yakni selain perawat bertugas dalam keperawatan medis, perawat juga harus menjalin interaksi dengan atasan kerja, rekan kerja, pasien, keluarga pasien dan juga masyarakat, dimana hal tersebut berpeluang menimbulkan stress (Lailani, 2014).

Bandura (1972) mengemukakan bahwa manusia yang efikasi dirinya kuat akan meningkatkan prestasi pribadi dalam berbagai strategi. Hal ini menentukan bahwa jika perawat yang memiliki efikasi diri yang tinggi akan berusaha meraih prestasi, lebih optimis dan selalu mencoba mencari solusi pemecahan tugas-tugas yang sulit. Individu yang memiliki efikasi diri yang tinggi akan memiliki rasa optimisme yang tinggi, dapat menurunkan rasa takut akan kegagalan karena individu tersebut lebih berani mengambil resiko. Individu mempunyai kepercayaan diri yang tinggi berkaitan dengan kemampuan dalam bekerja dibandingkan dengan individu yang memiliki efikasi diri yang rendah. Individu dengan efikasi diri yang rendah (kurang keyakinan pada kemampuannya untuk melaksanakan tugas- 
tugas dengan sukses) cenderung untuk berfokus pada ketidakadekuatan yang dipersepsikannya (Rathus \& Nevid, 1991).

Hasil penelitian berikutnya menunjukan bahwa ada hubungan antara dukungan sosial keluarga dengan burnout, yang artinya dukungan sosial keluarga merupakan salah satu faktor yang penting dalam menurunkan burnout perawat. Hasil analisis data menunjukan sumbangan efektif dari variabel dukungan sosial keluarga sebesar 16,51\%, yang artinya dukungan sosial keluarga mempengaruhi burnout. Hal tersebut sesuai dengan penelitian yang dilakukan Lailani (2012) bahwa dukungan sosial berkorelasi negatif dengan burnout pada perawat. Hal ini menunjukkan bahwa semakin besar dukungan sosial yang diperoleh perawat maka akan semakin rendah burnout yang dialami perawat. Dukungan sosial yang diterima perawat dari atasan, rekan kerja, dan keluarga dapat berfungsi sebagai sumber coping yang membantu perawat dalam menghadapi situasi yang menekan serta mengurangi pengaruh buruk dari peristiwa-peristiwa yang penuh tekanan. Selanjutnya, Cohen dan Wills (dalam Baron \& Byrne, 1984) juga mengungkapkan bahwa dukungan sosial dapat berfungsi menjaga kesehatan individu sehingga tetap sehat walau dalam situasi stres sekalipun, serta menjadi buffer dan membantu individu dalam menghadapi stres

Brehm dan Kassin (1990) mengemukakan bahwa dukungan sosial merupakan sumber potensial yang diberikan oleh orang lain dalam proses coping terhadap stres. Dukungan sosial keluarga merupakan pelindung untuk melawan perubahan-perubahan peristiwa dalam hidup yang penuh stres. Melalui dukungan sosial keluarga, akan meningkatkan kesejahteraan psikologis karena adanya perhatian dan pengertian yang menimbulkan perasaan memiliki, meningkatkan harga diri dan kejelasan identitas diri serta memiliki perasaan positif mengenai diri sendiri (Ramdan \& Fadly, 1970).

Perawat yang mendapatkan dukungan sosial keluarga yang tinggi dari orang-orang terdekatnya termasuk keluarga akan menimbulkan rasa dicintai, diperhatikan, dan kenyaman yang dapat memberikan kebaikan, pelayanan, dan saling menjaga ketika berada dalam situasi yang penuh tekanan sehingga akan berusaha untuk fokus menjalankan pekerjaannya sehingga dapat meminimalisir terjadinya burnout, sebagaimana hasil penelitian Tipandjan (2012) yang menyimpulkan dukungan sosial dari keluarga dan rekan kerja berhubungan signifikan dengan burnout perawat di Rumah Sakit Umum Puducherry India. Hasil penelitian ini sejalan dengan penelitian sebelumnya yang dilakukan oleh Ali Khalafi dan Osanloo (2014) yang menyimpulkan dukungan sosial keluarga menjadi variabel mediator terjadinya stres kerja dan burnout pada perawat.

Penelitian Aristiani dan Dwityanto (2015) menjelaskan bahwa dukungan informasi, seperti nasehat atau saran yang diberikan oleh orang-orang yang pernah mengalami keadaan yang serupa akan membantu individu memahami situasi dan mencari alternatif pemecahan masalah atau tindakan yang akan diambil. Adanya dukungan instrumental, menggambarkan tersedianya materi atau adanya pelayanan dari orang lain yang dapat membantu individu dalam menyelesaikan masalahnya sehingga memudahkan individu untuk dapat memenuhi tanggung jawab dalam menjalankan perannya sehari-hari hal tersebut dapat mengurangi burnout yang dialami individu.

Berdasarkan hasil kategorisasi variabel burnout dari 30 sampel penelitian diperoleh 80\% berada pada kategori sedang, yang menunjukkan burnout yang dialami perawat Rumah Sakit Umum Daerah Kota Soe belum sampai pada pekerjaan perawat. Hasil kategorisasi variabel efikasi diri diketahui bahwa mayoritas subjek penelitian memiliki efikasi diri pada kategori sedang, sesuai dengan asumsi peneliti melalui wawancara yang dilakukan sebelum penelitian. Berdasarkan hasil penelitian ini dapat dikatakan bahwa secara umum subjek penelitian cukup memiliki pandangan yang positif terhadap dirinya sendiri yang menunjukkan perawat cukup percaya diri, dan mampu melakukan pekerjaannya dengan baik. Hasil kategorisasi variabel dukungan sosial keluarga diketahui bahwa mayoritas subjek 
penelitian memiliki dukungan sosial keluarga pada kategori sedang. Hasil penelitian ini menjelaskan bahwa secara umum subjek penelitian cukup memiliki dukungan sosial dari keluarga baik dukungan emosional, penghargaan, instrumental dan informasi, sehingga dapat dikatakan subjek penelitian cukup mendapatkan rasa empati dan perhatian dari keluarganya sehingga menimbulkan rasa nyaman, merasa dirinya dihormati dan dihargai sehingga perawat tidak takut dalam mengambil keputusan, serta perawat mendapatkan nasihat dan bimbingan dari anggota keluarganya.

Penelitian ini masih memiliki keterbatasan yaitu pada kurangnya kontrol pada sampel penelitian, maka bagi peneliti selanjutnya disarankan agar dapat melakukan kontrol pada subjek penelitian tidak hanya menggunakan usia dan jenis kelamin tetapi dapat menggunakan kareritistik lainnya seperti status perkawinan, status kepegawaian, maupun berapa lama bekerja, sehingga memiliki data yang lebih kaya untuk dikaji.

\section{Simpulan}

Ada hubungan yang sangat signifikan antara efikasi diri dan dukungan sosial keluarga dengan burnout pada perawat RSUD Kota Soe. Efikasi diri memiliki hubungan negatif yang sangat signifikan antara dengan burnout pada perawat RSUD Kota Soe. Artinya, semakin tinggi efikasi diri maka semakin rendah burnout pada perawat RSUD Kota Soe, sebaliknya semakin rendah efikasi diri maka semakin tinggi burnout pada perawat. Dukungan sosial keluarga juga menunjukan adanya hubungan negatif yang sangat signifikan dengan burnout, yakni semakin tinggi dukungan sosial keluarga maka semakin rendah burnout pada perawat, sebaliknya semakin rendah dukungan sosial keluarga maka semakin tinggi burnout pada perawat.

\section{DAFTAR PUSTAKA}

Ali Khalafi, Y. T., \& Osanloo, S. (2014). Relationship between job stress and social support and burnout in nurses. Journal of Novel Applied Sciences, 3(1), 48-52.

Alverina, P. A. T., \& Ambarwati, K. D. (2019). Hubungan antara self-efficacy dengan burnout pada perawat psikiatri di rumah sakit jiwa. Jurnal Psikologi MANDALA, 3(2), 29-39. https://jurnal.undhirabali.ac.id/index.php/JPM/article/view/1094.

Andarika, R. (2004). Burnout pada perawat puteri RS St. Elizabeth Semarang ditinjau dari dukungan sosial. Jurnal PSYCHE, 1(1), 1-8.

Atkinson, R. I., Atkinson, R. C., \& Hilgard, E. R. (996). Pengantar psikologi jilid II. Jakarta: Erlangga.

Azwar, S. (1999). Penyusunan skala psikologi. Pustaka Pelajar. https://books.google. co.id/books?id=XXM6twAACAAJ.

Bandura, A. (1972). Self-efficacy: The Exercise of Control. W.H. Freeman. https://books. google.co.id/books?id=e\%5C_d4nQEACAAJ.

Baron, R. A., \& Byrne, D. E. (1984). Social psychology: Understanding human interaction. Allyn and Bacon. https://books.google.co.id/books?id=3xvmAAAAIAAJ.

Baron, R. A., \& Greenberg, J. (1990). Behavior in organizations: Understanding and managing the human side of work (Issue V. 1). Allyn and Bacon. https://books.google.co.id/ books?id=1\%5C_Nm8YELw-AC.

Brehm, S. S., \& Kassin, S. M. (1990). Social psychology. Houghton Miflin Company.

Djara, J. A. (2013). Perbedaan kelelahan kerja (burnout) antara perawat laki-laki dan perawat perempuan di RSUD Kota Soe. Skripsi.

Aristiani, E. Y. S., \& Dwityanto, A. (2015). Hubungan antara dukungan sosial dengan burnout pada perawat. Eprints UMS, 151(1), 10-17. http://eprints.ums.ac.id/37608.

Ivancevich, J. M., \& Matteson, M. T. (1993). Organizational behavior and management. Irwin. https://books.google.co.id/books?id=tiuFQgAACAAJ. 
Kementrian Kesehatan. (2010). Peraturan menteri kesehatan tentang klasifikasi rumah sakit. https://peraturan.bpk.go.id/Home/Details/139223/permenkes-no-340menkesperiii 2010-tahun-2010.

King, L. (2014). General psychology. McGraw-Hill Companies. https://books.google.co.id/ books?id=UOP9sgEACAAJ.

Lailani, F. (2012). Bournout pada pesawat ditinjau dari efikasi diri dan dukungan sosial. Jurnal Talenta Psikologi, 1(1). https://www.jurnal.usahidsolo.ac.id/index.php/ JTL/article/view/625.

Lailani, F. (2014). Burnout pada perawat ditinjau dari efikasi diri dan dukungan sosial di rumah sakit "XYZ" di Surakarta (nurses burnout in terms of self efficacy and social support at "XYZ" hospital of Surakarta). Jurnal Talenta Psikologi, 3(1). https:// www.jurnal.usahidsolo.ac.id/index.php/JTL/article/view/607.

Maslach, C. (1998). A multidimensional theory of burnout. Theories of organizational stress. Mind Garden.

Maslach, C., \& Jackson, S. E. (1981). The measurement of experienced burnout. Journal of Organizational Behavior, 2(2), 99-113. https://doi.org/https://doi.org/10.1002/ job.4030020205.

Pangastiti, N. K. (2011). Analisis pengaruh dukungan sosial keluarga terhadap burnout pada perawat kesehatan di rumah sakit jiwa. 127-134.

Pemerintah Pusat. (2009). Undang-undang (UU) tentang rumah sakit. https://peraturan. bpk.go.id/Home/Details/38789/uu-no-44-tahun-2009.

Prestiana, N. D. I., \& Purbandini, W. (2012). Hubungan antara efikasi diri (self efficacy) dan stres kerja dengan kejenuhan kerja (burnout) pada perawat IGD dan ICU RSUD Kota Bekasi. Jurnal Soul, Vol. 5, No. 2.

Putra, B. S., \& Fihir, I. M. (2013). Analisis faktor-faktor penyebab stres kerja pada perawat pelaksana Rumah Sakit Tugu Ibu Cimanggis. FKM Universitas Indonesia, 2013.

Ramdan, I. . M., \& Fadly, O. N. (1970). Analisis faktor yang berhubungan dengan burnout pada perawat kesehatan jiwa. Jurnal Keperawatan Padjadjaran, 4(2). https://doi.org/ 10.24198/jkp.v4i2.240.

Rathus, S. A., \& Nevid, J. S. (1991). Abnormal psychology. Prentice Hall. https://books.google. co.id/books?id=j-M2AQAAIAAJ.

Sarafino, E. P., \& Smith, T. W. (2014). Health psychology: Biopsychosocial interactions. Wiley. https://books.google.co.id/books?id=ypODBgAAQBAJ.

Schaufeli, W. B., \& Janczur, B. (1994). Burnout among nurses: A Polish-Dutch comparison. Journal of Cross-Cultural Psychology, 25(1), 95-113. https://doi.org/10.1177/ 0022022194251006.

Smet, Bart. (994). Psikologi Kesehatan. Jakarta: PT. Gramedia Widiarsana Indonesia.

Sulistyowati, P. (2010). Hubungan antara burnout dengan self efficacy pada perawat di ruang rawat inap RSUD Prof. Dr. Margono soekarjo purwokerto. 2(4), 1-27.

Taylor, S. E. (2017). Health psychology. McGraw-Hill Education. https://books.google.co.id/ books?id=qGJDDQEACAAJ.

Tipandjan, A. (2012). Nurses burnout: Does personality and social support relate? Journal of Organisation and Human Behaviour, 49-53. 